\title{
РЕПРЕССИВНАЯ НАПРАВЛЕННОСТЬ УГОЛОВНОГО ПРАВА: ЕСТЬ ЛИ КАКИЕ-ЛИБО ДОЛГОСРОЧНЫЕ ПОСЛЕДСТВИЯ?
}

\author{
Камбовски В.
}

Аннотация: Предметом исследования является изучение развития современного уголовного права в последние два десятилетия, которые характеризуются активизацией поиска новых ответов на вызовы организованных и других новых, нетрадиционных форм преступности. Анализируется традиционная система уголовного правосудия, которая поставила ряд требований: переоценка выбора институтов, как уголовной ответственности по отношению к ответственности юридических лиц, так и системе уголовных санкиий-ужесточение уголовной репрессии и новые санкиии, в частности, имущественного характера, необходимые для создания адекватной системы инкриминирования. Методами исследования являются: сравнительно-правовой, исторический, диалектический, анализа и синтеза, обобщающий, инновационный, оценок, прогнозирования, конкретизации. Научная новизна заключается в комплексном исследовании ряда уголовно-правовых проблем в Македонии и предложениях автора по их решению в соотношении с международным законодательством и практикой применения в других странах. В частности, автором рассматривается обязанность прогнозировать состояние уголовной ответственности юридических лиц в Македонии на основе изучения опыта нескольких странах и закреплений такой обязанности в некоторых международных конвенциия.

Ключевые слова: Уголовное право, конвенция, организованная преступность, прогнозирование, уголовная ответственность, преступность, формьл, деятельность, инновации, преступная деятельность.

Развитие современного уголовного права в последние два десятилетия характеризуются активизацией поиска новых ответов на вызовы организован- ных и других новых, нетрадиционных форм преступности. Между тем, традиционная система уголовного правосудия поставила ряд требований: пере- 
оценка выбора институтов, как уголовной ответственности по отношению к ответственности юридических лиц, так и системе уголовных санкций - ужесточение уголовной репрессии и новые санкции, в частности имущественного характера, а также для создания адекватной системы инкриминирования.

Но самые современные способы, как реагировать на организованную преступность, а также осознание его веса и серьезности, которая не вызывает реакции в законодательстве, будет поворотом в нем и некоторые называют себя «символическим» или законодательством «панино» (Schuler-Springorum , 19). Первое означает установление слабого прогноза, который должен быть достигнут, второй очереди принятие недостаточного обзора с предложениями об эффективности. Совершенно очевидно, что эпоха уголовного права должна быть удалена от этой опасности. Для того, чтобы дать в этом случае тщательный государственно-правовой принцип уголовного права, как последний довод добиться уголовно-правовой реакции на быстрые и эффективные средства предупреждения преступности, означает средство удержания усилий по устранению причин возникновения преступности и принятие стабильной программы борьбы с новыми возникающими формами преступности. Новые формы организованной преступности не могут быть эффективными без подавляющей комплексной профилактической деятельности во всех областях социальных отношений культуры, политики и экономики, в правовой системе.

Организованная преступность увеличилась, как говорят наблюда- тели, в качестве наиболее серьезного качества жизни, чтобы оправдать применение «чрезвычайных» уголовно-правовой меры, основанные на идее необходимой обороны современного общества. Многие авторы, особенно немецкие (Jacobs) в таких новых формах реакции, с помощью которых отклоняются от некоторых классических нескольких принципов и институтов уголовного права (уголовная ответственность юридических лиц, специальных следственных мероприятий, передача бремени сохранения на ответчика и т.д.), они видят в рождении новой концепции - «враждебной», в противоположность «гражданскому», уголовного права: в законе рецидивист рассматривается как источник опасности для общего блага, это оправдывает изменения уголовноправового вмешательства в начальной стадии преступной деятельности (наказание подготовки, организации для выполнения преступной деятельности и т.д;.. V. Stegmann, 3). В уголовноправовом «лечении» организованной преступности растет, другими словами, в концепции уголовного права «на основе на правонарушителя», в противоположность либеральной идеи для уголовного права «на основе работы уголовного дела». Возражения мной «враждебного» и гражданского» уголовного права влияет на переопределение его функции защиты нагрузки: регулирует ли социальные конфликты, или идет способом их возникновения. Современное уголовное право стоит, значит, перед новыми вызовами, в которой вы должны найти баланс между, с одной стороны, 
необходимостью усиления защиты общества от организованной преступности, сдвиги с уголовно-правовым вмешательством в начальной фазе, a с другой стороны, необходимость защиты индивидуальных свобод и уважения государственными и юридических постулатов. Баланс между двумя требованиями реализуется в принципе с расширением уголовноправовых мер в материальном уголовном праве, в то время укрепление гарантий защиты прав обвиняемого в уголовном процессуальном праве.

\section{2. Инновации в уголовном законодательстве и их согласование}

2.1. Многие недовольны тем, что существует обзор уголовного правосудия, в отношении которых он считает, что ни один них не представляют собой адекватный ответ на вызов организованных и других новых форм преступности, я уже достиг требуемой «критической массы», которая поощряет происходящие реформы в уголовном законодательстве государства. Разработка различных моделей являются: принятие специальных законов для организованной преступности; запрос обзора в рамках уголовного права; комбинированная модель; очередное нововведение в уголовное законодательство предполагает принятие специальных законов (для предотвращения коррупции, отмывания денег и т.д.); а также изменения в уголовно-процессуальном законодательстве. Совместная особенность состоит в том, что вся очевидная динамика изменения уголовного законодательства, даже в традиционной системе уголовного правосудия; как немец, новый законодательной обзор составил на основе повседневной политики.

$\mathrm{B}$ европейском уголовном законодательстве, чтобы открыть несколько направлений для изменения. Первое выступление ужесточения репрессий на «преступные организации», в некоторых законодательных актах навеяна англо-саксонскими учреждениями по вопросам обороны («заговор»). Второй заключается в криминализации преступлений, предусмотренных для меня международными конвенциями (для организованной преступности, отмыванием денег, коррупцией, киберпреступностью и т.д.), принятых в течение последних двух десятилетий. Третье направление представляет продление репрессии включающее уголовную ответственность юридических лиц; четвёртую представляют систему штрафов и средств более строгого лечения в случае организованной преступной деятельности и применения конфискации преступных доходов), пятый относится к изменениям в процесс законодательства, укрепление позиций полиции и прокуратуры, введение новых доказательств и правил доказывания, обусловленности специальных следственных мероприятий и широкое внедрение модели государственнопрокурорского расследования.

В столкновении между «пацифистской и Belisti», подобные изменения в линии новой концепции «беллум justum», стало основной линией ужесточения уголовной репрессии (Schneider, 501.). 
2.2. Скорость, с которой происходят реформы системы уголовного правосудия он не может оправдать отсутствие серьезного анализа последних тенденций в области уголовного законодательства, будет смущать их в контексте легитимности уголовного репрессий и основной концепции и функции уголовного права в демократических правовых отношениях. Такой анализ обязательно предполагает наблюдение, что любые изменения в отношении: концепции уголовное право защиты, направленные на человеческое достоинство, свободу и права; система индивидуальной и социальной стоимости; основа, роль и масштабы репрессивных полномочий государства. Они сосредоточены на применении закона, который обрабатывает использование всех репрессивных средств которые и находятся в распоряжении, есть ли у нее оригинальная компетентность, что размер пенитенциарной правовой репрессии выбирается произвольно, в соответствии с их интересами. Что сделать, чтобы избежать опасности от преступления для запугивания; вмешательство на свободы и права человека должны быть заменены опасности страны, когда усиление репрессивных мер могут быть объяснены и объясняется необходимостью для защиты физического лицо в совершении преступления?

То, что мы рассмотрим, например, конвенции СЕ, ЕС и ON, которые предусматривают обязательство для внедрения эффективных и жестких санкций за коррупцию, а вместе с ними и установленным национальным законодательством, что они реализуются. Их применение сталкивается с тем, что не только в пост-trancicionite, но и в развитых европейских странах коррупцией является исключительно криминальное явление, но это системная проблема в функционировании государств. Пресечение коррупции в постпереходной стране, является неэффективным в общем из-за конституционных недостатков в системах политики, которые вызывают закупорку системы уголовного правосудия.

Для решения подобных проблем наткнулся на законодательные тенденции укрепления репрессий в отмывании денег, он считает спасающие жизнь формулы, реализация которых, через запрет отмывания преступных доходов, приведет к сокращению преступности, такие и демотивируют виновных в совершении преступных деяний. В результате применения многочисленных конвенций (последняя е Конвенция о предотвращении отмывания денег и финансирования терроризма в SE 2005) будет только чрезвычайно меняться из года в год; уголовно-правовой запрет в национальном законодательстве (положения, содержащегося в Уголовном кодексе Республики Македонии , L.273, е диапазоны обеспечения уголовноправовой цены, имеют тенденцию к росту на отдельные группы, которые будут уголовными, но и специальную главу в специальной части уголовного кодекса). Напротив нормативной строгости, в судебной практике нет ничего впечатляющего - на пальцах одной руки нельзя сосчитать обвинительные заключения для этой работы или окончательное судебное решение. Одним из них является от- 
ветом на вызовы эпохи и заключается в следующем: речь идет о системной проблеме, это не в степени свободы и не нельзя сказать, что в средствах на уголовное право.

Поиск более эффективных средств подавления организованных и других новых форм преступности на таких преступных политиков основной упор приводят к появлению в европейском уголовном законодательстве «института расширенной конфискации», так как это включает в себя не только использование непосредственных доходов, полученных от конкретной работы, которые подлежат обвинению, но иного имущества преступника, для которого есть обоснованные сомнения в том, что он получил их в качестве преступной деятельности. Введение этого вида захвата в ЕС будет способствовать принятию рамочного решения Совета министров ЕС по конфискации преступных доходов с 2005 года (условия строго определены в L.3). Увеличенная конфискация была введена в ряде Большинства европейского законодательства (немецкого, австрийского, венгерского, голландского и т.д. В Македонии был введен в инновации 2009 года). Уголовно-правовая теория, в противном случае однажды в знак признания важности конфискации в качестве меры потребовала, не является уникальным об обосновании расширенной конфискации, особенно с точки зрения уважения основных принципов уголовного права: принцип вины за преступление, принцип справедливости наказания за совершение преступления, а также презумция невиновности. Выбранная вами ставка зависит, в частности, по проблеме ответчика на бремя законодательства, что некоторое свойство и является законным. Очевидно, что вопрос не только теоретической дилеммы, но что они заботятся, чтобы проводилась и судебная практика (с момента введения в Уголовный кодекс Республики Македонии в 2009 году до сегодняшнего дня, эта мера не применяется в одном случае в македонском судебной практике).

Эти примеры новых типов инкриминирования и новых институтов уголовного правосудия, серии, которые выражают тенденцию ужесточения борьбы с новыми формами преступности, указывают на устойчивое внимание и порции критики по отношению к созданию и применению мер международных конвенций, и пути гармонизация национального законодательства, чтобы избежать опасности нормативного иллюзионизма, которая не очень помогает в эффективном пресечении преступлений. Даже в некотором роде и идут промахи, поэтому концентрирует огромную власть и другие власти должны быть отклонены к осу ществлению текущего применимого обзора, с высокой степенью риска для выборочного применения, рассчитанные исключительно на укрепление общего профилактического действия закона, они пренебрегают запросы для профилактики и для уважения прав и свобод человека. Некоторые нововведения в уголовном законодательстве, управленческие в первой строке запроса на эффектив- 
ности уголовного правосудия и гармонизации законодательств, имеют слабую научную и экспертную базу. Реже применяют метод организации подготовительного обсуждения в международном масштабе и национальных рамках, к которым следует проверять действительность и применимость найти новую теорию и наличие многочисленных предположений (организационных, м материальных, технических, образовательных, людских ресурсов) для их применения.

2.3. Была выражена тенденция ужесточения уголовно-правовой репрессии и введения уголовной ответственности юридических лиц и усиленное уголовно-правовое вмешательство в частный (экономический) сектор. Она опирается, прежде всего, на признании того, что юридические лица возникают в качестве субъектов в различных формах преступности (массовое мошенничество на потребителей личных, финансовых, банковских и биржевых операций, криминальные ложные банкротства и т.д.), относящиеся не только экономической, но и другим новым формам преступности (терроризм, отмывание денег, экологические преступления, коррупция и т.д.). Актуален и более глубокий глобальный экономический кризис худшим образом продемонстрировавший коррумпированность банковской и финансовой системы на глобальном и национальном уровне и, как клубок из глубоких противоречий в современном мире, которые являются основными факторами возникновения новых форм преступности.
Обязанность состояния прогнозировать уголовную ответственность Юридических лиц в нескольких странах закреплена в ряде международных конвенций. Особым знанием является Конвенция о транснациональной организованной преступности 2000 года (Палермо), которая требует такой ответственности, чтобы быть подписала единогласно правовые принципы, касающиеся домашнего законодательства и что влечет за собой эффективные и соразмерные санкции (L.26). Рамочное решение по борьбе с организованной преступностью в Совете министров EC в 2005 году содержит обязательство государств предусмотреть уголовную ответственность юридических лиц за деяния, совершенные в наивном состоянии в пользу лиц, которые поступают индивидуально или в качестве членов полномочия юридического лица и имеют в ней руководящую должность (L.5 и 6). Во всех конвенциях и других документах четко определено, что это понятие относится к юридическим лицам, в частном секторе, но за исключением электронной базы или других государственных органов, или международные организации (тот же рамочное решение L.1; с соответствии с этим решением, работающих над активной и пассивной коррупции может при исполнении хозяйственной деятельности на прибыль или некоммерческих юридических лиц).

Установленная уголовная ответственность юридических лиц является одним из основных двигателей реформы в уголовном законодательстве. 
Такое нововведение было принято и в законодательствах в состоянии переходного периода. Ряд сравнительных анализов указывает на ряд различий между ними, что приоритет в отношении; исходя из ответственности: при каких условиях уголовной работы он может цепляться к юридическому лицу и что субъективные предположения об ответственности конкретного лица всегда ведет к ответственности юридического лица. Это не является точным и в утверждении на взимание штрафов право регулируется, и ответственность государственных юридических лиц в области хозяйственных функций (государственных предприятий, находящихся в собственности и т.д.) Он не регулирует ни правовую ответственность за передачу надзора коллективного принятия решений и ответственности коллективных органов (Ассамблея, Совет директоров Общества) и их членов, уполномоченных лиц или законных представителей юридического лица.

В переходной системе, в системах не интегрирована модель рыночной экономики и остается сильным регулирование государства и вмешательство (теперь желтый и усилил оправдание, что государства в условиях глобального экономического кризиса должны идти спасать экономику), а не созданы условия для эффективной ответственности юридических лиц. Это основные причины новой эры теорий, которые не будут применяться на практике (в македонском практике зарегистрированы только после обвинительных нескольких лет, которые не относятся к сценариям форм организованной преступной деятельности: взяточничество, злоупотребление тендерных процедур и т.д.).

2.4. Специальная зона, на которой тенденция ужесточения уголовно-исполнительной репрессии непосредственно в контакте с концепцией прав и свобод человека является выявление и преследование новых форм преступности, внедрение новых методов и средств, мотивируют к развитию и большей эффективности уголовного правосудия. Модернизация системы уголовного правосудия из компетенции органов выявлять и привлекать к ответственности, таким образом, что больше процедурные знания получают более низкую оценку, на ранней стадии обнаружить и преследовать в судебном порядке, укрепление позиции прокурора и передачи полномочий осуществлять формальные процессуальные действия полиции (ст. Stegmann, 128).

Эта тенденция проявляется вниз введения специальных следственных мер, временных мер по замораживанию и конфискации, продолжение содержания и расширение принципа оппортунизма, используя защищенных свидетелей и так далее. Запрос, повышение эффективности в системе уголовного правосудия должно осуществляться в соответствии с оплатой демократического правового государства, наряду с уважением ее государственно- правовых принципов прав и свобод человека, государственная настоящая эрозия гибкой интерпретации этих принципов. В последнее время общедоступную 
тенденцию, например, применение специальных следственных действий на прослушивание телефонных разговоров и аудио - записи, чтобы продлить безнаказанность и подготовительные действия (такие в Законе о македонском для перехвата сообщений после внесения поправок в 2008 году).

Особенно проблематичными с точки зрения эффективного осуществления нового процесса теории и ослабление позиции презумции невиновности, это имеет далеко идущие последствия по отношению к уголовно-правовой системе в целом. В международном и национальном регулировании его прорыв был выполнен в состыковке из предыдущих работ, что является условием для существования криминализации отмывания денег. В конвенциях организованной преступной деятельности (Палермо такой конвенции, L.12) устроить передачу запроса от бремени доказывания на правонарушителя, который в соответствии с платой личного права и характер судебных и других процедур. Очевидно, несомненно, вы несете бремя на обвиняемого какого приговора конфискация или доказываете на прогностические работы априори не в согласии с презумпцией невиновности. Аналогичная ситуация с использованием доказательств, полученных незаконным путем в результате применения специальных следственных мероприятий, что в круг вокруг этой презумпции, что подразумевает любой вид запрета на самообвинение. К числу этого мнения, в уголовно-правовой теории не является небольшое число сторонников, что на использование такого мнения, как предполагается, действуют реальные проблемы, с которыми сталкивается судебная практика. Суды именно не готовы выносить решения только на основе предположений и без безопасной доказательной базы вины. Следовательно, оправдано мнение, что в тех случаях, в которых больше не соответствовал нормам доказывания, основанной на презумпции невиновности, нельзя достичь более низкого стандарта (обоснованные сомнения) и не нужно идти к уголовной ответственности и наказания, но и по другим аспектам ответственности: так, например, по отношению к коррупции, возможно эффективное осуществление международного запрета и со ссылкой на нарушение или дисциплинарной ответственности.

\section{Библиография:}

1. Schneider V. Crime. Ckopje, 2011. C. 501.

2. Kambovski V.I. Preduprezhlenie crime. Ckopje, 2013. C. 155.

\section{References (transliterated):}

1. Schneider V. Crime. Ckopje, 2011. C. 501.

2. Kambovski V.I. Preduprezhlenie crime. Ckopje, 2013. C. 155. 